ҚАЗАҚСТАН РЕСПУБЛИКАСЫ

ҰЛТТЫҚ ҒЫЛЫМ АКАДЕМИЯСЫНЫН

АБАЙ АТЫНДАҒЫ ҚАЗАҚ ҰЛТТЫҚ

ПЕДАГОГИКАЛЫҚ УНИВЕРСИТЕТІНІҢ

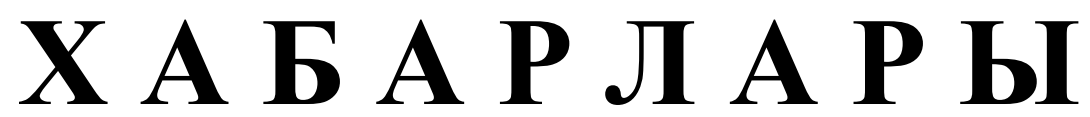

\section{ИЗВЕСТИЯ}

НАЦИОНАЛЬНОЙ АКАДЕМИИ НАУК РЕСПУБЛИКИ КАЗАХСТАН

КАЗАХСКИЙ НАЦИОНАЛЬНЫЙ

ПЕДАГОГИЧЕСКИЙ УНИВЕРСИТЕТ ИМ. АБАЯ

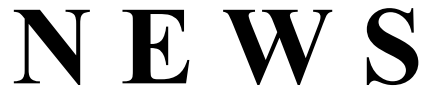

OF THE NATIONAL ACADEMY OF SCIENCES OF THE REPUBLIC OF KAZAKHSTAN

ABAY KAZAKH NATIONAL PEDAGOGICAL UNIVERSITY

ҚОҒАМДЫҚ ЖӘНЕ ГУМАНИТАРЛЫҚ ҒЫЛЫМДАР СЕРИЯСЫ

СЕРИЯ ОБЩЕСТВЕННЫХ И ГУМАНИТАРНЫХ НАУК

SERIES OF SOCIAL AND HUMAN SCIENCES

\author{
6 (322) \\ ҚАРАША - ЖЕЛТОҚСАН 2018 ж. \\ НОЯБРЬ - ДЕКАБРЬ 2018 Г. \\ NOVEMBER - DECEMBER 2018 \\ ИЗДАЕТСЯ С ЯНВАРЯ 1962 ГОДА \\ PUBLISHED SINCE JANUARY 1962 \\ ЖЫЛЫНА 6 РЕТ ШЫҒАДЫ \\ ВЫХОДИТ 6 РАЗ В ГОД \\ PUBLISHED 6 TIMES A YEAR
}

1962 ЖЫЛДЫҢ ҚАНТАР АЙЫНАН ШЫҒА БАСТАҒАН 
Ба с ре дактор

ҚР ҰҒА кұрметті мүшесі

Балықбаев Т.O.

Р е д а ц и я а лқ а сы:

экон. ғ. докторы, проф., ҚР ҰҒА академигі Баймұратов У.Б.; тарих ғ. докторы, проф., ҚР ҰҒА академигі Байпақов К.М.; филос. ғ.докторы, проф., ҚР ҰҒА академигі Есім Г.Е.; фил. ғ. докторы,, проф., ҚР ҰҒА академигі Қирабаев С.С.; эк. ғ. докторы, проф., ҚР ҰҒА академигі Кошанов А.К.; эк.ғ. докторы, проф., ҚР ҰҒА академигі Нәрібаев К.Н. (бас редактордың орынбасары); филос. ғ.докторы, проф., ҚР ҰҒА академигі Нысанбаев А.Н.; заң ғ. докторы, проф., ҚР ҰҒА академигі Сәбікенов С.Н.; заң ғ. докторы, проф., ҚР ҰҒА академигі Сүлейменов М.К.; эк. ғ. докторы, проф., ҚР ҰҒА академигі Сатыбалдин С.С.; тарих ғ. докторы, проф., ҚР ҰҒА академик Әбжанов Х.М.; тарих ғ. докторы, проф., ҚР ҰҒА корр. мүшесі Әбусеитова М.Х.; тарих ғ. докторы, проф., ҚР ҰҒА академик Байтанаев Б.А.; филол. ғ. докторы, проф., ҚР ҰҒА корр. мүшесі Жақып Б.А.; фил. ғ. докторы, проф., академик НАН РК Қалижанов У.К.; филол. ғ. докторы, проф., ҚР ҰҒА академик Қамзабекұлы Д.; тарих ғ. докторы, проф., ҚР ҰҒА академик Қожамжарова Д.П.; тарих ғ. докторы, проф., ҚР ҰҒА академик Койгелдиев М.К.; фил. ғ. докторы, проф., ҚР ҰҒА корр. мүшесі Кұрманбайұлы Ш.; тарих ғ. докторы, проф., ҚР ҰҒА корр. мүшесі Таймағанбетов Ж.К.; социол. ғ. докторы, проф., ҚР ҰҒА корр. мүшесі Шәукенова 3.К.; фил. ғ. докторы, проф., КР ҰҒА корр. мүшесі Дербісәлі А.; саяси. ғ. докторы, проф., Бижанов А.К., тарих ғ. докторы, проф., Кабульдинов 3.Е.; фил. ғ. докторы, проф., ҚР ҰҒА корр мүшесі Қажыбек Е.3.

\section{Р едакция ке н е с i:}

Молдова Республикасының ҰҒА академигі Белостечник Г. (Молдова); Әзірбайжан ҰҒА академигі Велиханлы Н. (Азербайджан); Тәжікстан ҰҒА академигі Назаров Т.Н. (Тәжікстан); Молдова Республикасының ҰҒА академигі Рошка А. (Молдова); Молдова Республикасының ҰҒА академигі Руснак Г. (Молдова); Әзірбайжан ҰҒА корр. мүшесі Мурадов Ш. (Әзірбайжан); Әзірбайжан ҰҒА корр. мүшесі Сафарова 3. (Әзірбайжан); э. ғ. д., проф. Василенко В.Н. (Украина); заң ғ. докт., проф. Устименко В.А. (Украина)

«Қазақстан Республикасы Ұлттық ғылым академиясының Хабарлары. Қоғамдық және гуманитарлық ғылымдар сериясы». ISSN 2224-5294

Меншіктенуші: «Қазақстан Республикасының Ұлттық ғылым академиясы» РҚБ (Алматы қ.)

Қазақстан республикасының Мәдениет пен ақпарат министрлігінің Ақпарат және мұрағат комитетінде 30.04.2010 ж. берілген № 10894-Ж мерзімдік басылым тіркеуіне қойылу туралы куәлік

Мерзімділігі: жылына 6 рет.

Тиражы: 500 дана.

Редакцияның мекенжайы: 050010, Алматы қ., Шевченко көш., 28, 219 бөл., 220, тел.: 272-13-19, 272-13-18, http://nauka-nanrk.kz. social-human.kz

(C) Қазақстан Республикасының Ұлттық ғылым академиясы, 2018

Типографияның мекенжайы: «Аруна» ЖК, Алматы қ., Муратбаева көш., 75. 
Главный редактор

Почетный член НАН РК

T.O. Балыкбаев

Р е дак ци онн а я коллег и я:

докт. экон. Н., проф., академик НАН РК У.Б. Баймуратов; докт. ист. н., проф., академик НАН РК К.М. Байпаков; докт. филос. Н., проф., академик НАН РК Г.Е. Есим; докт. фил. Н., проф., академик НАН РК С.С. Кирабаев; докт. экон. Н., проф., академик НАН РК А.К. Кошанов; докт. экон. Н., проф., академик НАН РК К.Н. Нарибаев (заместитель главного редактора); докт. филос. н., проф., академик НАН РК А.Н. Нысанбаев; докт. юр. Н., проф., академик НАН РК С.Н. Сабикенов; докт. юр. н., проф., академик НАН РК М.К. Сулейменов; докт. экон. Н., проф., академик НАН РК С.С. Сатубалдин; докт. ист. н., проф., академик НАН РК Х.М. Абжанов; докт. ист. н., проф., чл.-корр. НАН РК М.Х. Абусеитова; докт. ист. н., проф., академик НАН РК Б.А. Байтанаев; докт. фил. н., проф., чл.-корр. НАН РК Б.А. Жакып; докт. фиолол. н., проф., академик НАН РК У.К. Калижанов; докт. фил. н., проф., академик НАН РК Д. Камзабекулы; докт. ист. н., проф., академик НАН РК Д.П. Кожамжарова; докт. ист. н., проф., академик НАН РК М.К. Койгельдиев; докт. филол. н., проф., чл.-корр. НАН РК Ш. Курманбайулы; докт. ист. н., проф., чл.корр. НАН РК Ж.К. Таймаганбетов; докт. социол. н., проф., чл.-корр. НАН РК З.К. Шаукенова; д. филол. н., проф., чл.-корр. НАН РК А. Дербисали; доктор политических наук, проф., Бижанов А.К.; доктор ист. наук, проф., Кабульдинов 3.Е.; доктор филол. н., проф., член-корр. НАН РК Қажыбек Е.3.

Р е дак ци онны й с ов ет

академик НАН Республики Молдова Г. Белостечник (Молдова); академик НАН Азербайджанской Республики Н. Велиханлы (Азербайджан); академик НАН Республики Таджикистан Т.Н. Назаров (Таджикистан); академик НАН Республики Молдова А. Рошка (Молдова); академик НАН Республики Молдова Г. Руснак (Молдова); чл.-корр. НАН Азербайджанской Республики Ш. Мурадов (Азербайджан), член-корр. НАН Азербайджанской Республики 3.Сафарова (Азербайджан); д. э. н., проф. В.Н. Василенко (Украина); д.ю.н., проф. В.А. Устименко (Украина)

Известия Национальной академии наук Республики Казахстан. Серия общественных и гуманитарных наук. ISSN 2224-5294

Собственник: РОО «Национальная академия наук Республики Казахстан» (г. Алматы)

Свидетельство о постановке на учет периодического печатного издания в Комитете информации и архивов

Министерства культуры и информации Республики Казахстан № 10894-Ж, выданное 30.04.2010 г.

Периодичность 6 раз в год

Тираж: 500 экземпляров

Адрес редакции: 050010, г. Алматы, ул. Шевченко, 28, ком. 219, 220, тел. 272-13-19, 272-13-18, www:nauka-nanrk.kz / social-human.kz

(C) Национальная академия наук Республики Казахстан, 2018 г.

Адрес типографии: ИП «Аруна», г. Алматы, ул. Муратбаева, 75

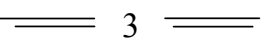


Chief Editor

\section{Honorary member of NAS RK \\ Balykbayev T.O}

Editorial board:

Doctor of economics, prof, academician of NAS RK Baimuratov U.B.; doctor of history, prof, academician of NAS RK Baipakov K.M.; doctor of philosophy, prof, academician of NAS RK Esim G.E.; doctor of philology, prof, academician of NAS RK Kirabayev S.S.; doctor of economics, prof, academician of NAS RK Koshanov A.K.; doctor of economics, prof, academician of NAS RK Naribayev K.N. (deputy editor-in-chief); doctor of philosophy, prof, academician of NAS RK Nyssanbayev A.N.; doctor of law, prof, academician of NAS RK Sabikenov S.N.; doctor of law, prof, academician of NAS RK Suleymenov M.K.; doctor of economy, prof, academician of NAS RK Satybaldin S.S.; doctor of history, prof, academician of NAS RK Abzhanov H.M; doctor of history, prof, corresponding member of NAS RK Abuseitova M.H.; doctor of history, prof, academician of NAS RK Baitanaev B.A.; doctor of philology, prof, corresponding member of NAS RK Zhakyp B.A.; doctor of philology, prof, academician of NAS RK Kalizhanov U.K.; doctor of philology, prof, academician of NAS RK Hamzabekuly D.; doctor of history, prof, academician of NAS RK Kozhamzharova D.P.; doctor of history, prof, academician of NAS RK Koigeldiev M.K.; doctor of philology, prof, corresponding member of NAS RK Kurmanbaiuly Sh.; doctor of history, prof, academician of NAS RK Taimaganbetov J.K.; doctor of sociology, prof, corresponding member of NAS RK Shaukenova Z.K.; doctor of philology, prof, corresponding member of NAS RK Derbisali A.; doctor of political science, prof Bizhanov A.K; doctor of History, prof Kabuldinov Z.E.; doctor of philology, prof, corresponding member of NAS RK Kazhybek E.Z.

\section{Editorial staff:}

Academician NAS Republic of Moldova Belostechnik.G (Moldova); Academician NAS Republic of Azerbaijan Velikhanli N. (Azerbaijan); Academician NAS Republic of Tajikistan Nazarov T.N. (Tajikistan); Academician NAS Republic of Moldova Roshka A. (Moldova) Academician NAS Republic of Moldova Rusnak G. (Moldova); Corresponding member of the NAS Republic of Azerbaijan Muradov Sh. (Azerbaijan); Corresponding member of the NAS Republic of Azerbaijan Safarova Z. (Azerbaijan); Associate professor of Economics Vasilenko V.N. (Ukraine), Associate professor of Law Ustimenko V.A. (Ukraine)

News of the National Academy of Sciences of the Republic of Kazakhstan. Series of Social and Humanities. ISSN 2224-5294

Owner: RPA "National Academy of Sciences of the Republic of Kazakhstan" (Almaty)

The certificate of registration of a periodic printed publication in the Committee of information and archives of the Ministry of culture and information of the Republic of Kazakhstan N 10894-Ж, issued 30.04.2010

Periodicity: 6 times a year

Circulation: 500 copies

Editorial address: 28, Shevchenko str., of. 219, 220, Almaty, 050010, tel. 272-13-19, 272-13-18, www:nauka-nanrk.kz / social-human.kz

(C) National Academy of Sciences of the Republic of Kazakhstan, 2018

Address of printing house: ST "Aruna", 75, Muratbayev str, Almaty 
N E W S

OF THE NATIONAL ACADEMY OF SCIENCES OF THE REPUBLIC OF KAZAKHSTAN

SERIES OF SOCIAL AND HUMAN SCIENCES

ISSN 2224-5294

Volume 6, Number 322 (2018), 260 - 264

https://doi.org/10.32014/2018.2224-5294.62

UDC 332.4:621.2.

\author{
K.M. Utepkalieva, R.K. Sabirova, G.U. Kenbaeva
}

Atyrau State University named after H. Dosmukhamedov, Atyrau, Kazakhstan kansulu77@mail.ru, sabirovarysty@mail.ru, $\underline{\text { k.aizhan94@mail.ru }}$

\title{
DEVELOPMENT OF PUBLIC PRIVATE PARTNERSHIP APPROACH IN OIL AND GAS OF KAZAKHSTAN
}

\begin{abstract}
The article discusses the possible directions of development of public-private partnership in the oil and gas industry. Success in the rational, efficient development and use of fuel and energy resources is largely determined by the innovative activity of enterprises, constant technological renewal of production and confirms the experience of successful oil and gas companies that have mastered several generations of new technologies over the past 25-30 years. To date, the use of public-private partnerships for modernizing the economy has become widespread, new priorities in using the practice of this partnership dictate new theoretical and methodological approaches to assessing the effectiveness of public-private partnerships - projects that, according to the authors, will result in additional budget revenues for growth account investment, production and employment.

Keywords: mineral raw materials, mineral energy, energy, energy, materials, plants, efficiency, production capacity.
\end{abstract}

\section{INTRODUCTION}

Kazakhstan has huge natural reserves of minerals. After the country acquired its sovereignty and independence, the extraction of carbon raw materials more than doubled, while worldwide growth of this indicator was 1.3 times.

Energy as an area of national economy includes a number of special and self-significant industries, namely: electricity, heat, gas industry, coal industry, oil industry.

The fuel and energy complex is a combination of the branches of the fuel industry, electric power industry, means of delivery of fuel and energy.

The structure of world consumption of primary energy sources today is as follows: oil - $34.1 \%$; coal $29.6 \%$; gas - $26.5 \%$; hydropower - $5.2 \%$; nuclear energy - $4.6 \%$.

The fuel industry is a complex of industries engaged in the extraction and processing of fuel and energy raw materials. Its significance lies in providing fuel and raw materials to other industries - heat and power engineering, petro chemistry, metallurgy, etc. Under the conditions of scientific and technological revolution, the role of the fuel industry increases due to the development of electrification and heat production, causing an intensive increase in energy consumption.

\section{MAIN PART}

The fuel industry includes the following industries:

- coal;

- oil;

- gas;

- peat;

- slate;

- uranium mining. 
The fuel and energy complex (FEC) is the basic basis for the development of the entire industrial complex of the country, and the use of the achievement of NTP helps reduce the cost component in the products and increase its competitiveness.

Fuel and energy resources play a leading role in the world mineral resource base. The development of society is invariably accompanied by a search for new materials and technologies, an increase in the number of consumer goods produced by industry, an expansion of their range and an improvement in quality. This trend is supported by increasing the volume of extraction and processing of mineral raw materials, in other words, the development of the world economy is associated with a steady increase in the use of mineral resources. Academician P.L. Kapitsa was one of the first who paid attention to the established D.Kh. Midovs has a strong correlation dependence of GDP on energy consumption, making the fundamental conclusion: "If people lose energy resources, their material well-being will fall" [1].

The Caspian Sea is a key region for European energy, however, it was not without problems. Despite the fact that the reserves of resources here make up $60 \%$ of Russian, there are no direct deliveries to Europe from here. Kazakh oil, as well as gas from Turkmenistan (the gas resources of which are equal to one third of the Russian gas reserves, although the territory of this state is 50 times smaller than Russia) could easily replace supplies from Moscow.

At present, the search for and active use of new alternative energy sources in many developed countries of the world have been adopted as vital, strategically necessary resources ensuring the prospective development of the economies of these countries.

In the Development Strategy of Kazakhstan until 2030, the leading role is given to the oil and gas industry. This is dictated by the fact that the Republic today belongs to the group of states possessing strategic hydrocarbon reserves, and influences the formation of the world energy market.

The fuel and energy complex (FEC) is the basic basis for the development of the entire industrial complex of the country, and the use of the achievement of NTP helps reduce the cost component in the products and increase its competitiveness.

Fuel and energy resources play a leading role in the world mineral resource base. The development of society is invariably accompanied by a search for new materials and technologies, an increase in the number of consumer goods produced by industry, an expansion of their range and an improvement in quality. This trend is supported by increasing the volume of extraction and processing of mineral raw materials, in other words, the development of the world economy is associated with a steady increase in the use of mineral resources. Academician P.L. Kapitsa was one of the first who paid attention to the established D.Kh. Midovs has a strong correlation dependence of GDP on energy consumption, making the fundamental conclusion: "If people lose energy resources, their material well-being will fall" [1].

The main challenges facing the fuel and energy complex of Kazakhstan:

1. Ensuring the country's energy security

2. Global energy consumption growth in the region's economies

3. Increasing competitiveness through energy and resource saving, increasing energy efficiency

4. Using the advantages of the geopolitical location of the country, transit and export potential

5. Use of country competitive advantages (coal, uranium, etc.)

6. Ecology and water and energy problems

7. Involvement in the energy balance of RES

8. The introduction of new technologies

9. Improving the safety of electrical equipment and power facilities, improving reliability, reducing accidents

10. Development of scientific potential

The economic resource of renewable energy sources (RES) in the world is currently estimated at 20 billion tons per year, which is 2 times higher than the annual production of all types of fossil fuels. This circumstance indicates the path of energy development in the near future [1].

An important achievement of the Republic of Kazakhstan is a dynamically developing foreign trade, a special place in which is occupied by the products of the fuel and energy complex. Natural gas reserves in Kazakhstan are estimated at 5.9 billion cubic meters. $m$ and gas condensate - 1438 million tons .. The area of promising oil and gas areas of the Republic of Kazakhstan is 1 million 700 thousand square meters. m, which is $62 \%$ of its entire territory. In Kazakhstan, 1.2 million barrels of oil are extracted daily, of which 1 
million is exported. The government plans to increase production to 3.5 million barrels per day by 2015 , having caught up with Iran on this indicator.

The presence of a development strategy and the ability to realize it are closely related to the potential of natural resources. If the wealth of the subsoil is the property of all subsequent generations, then a thought-out strategy and its implementation are the key to achieving this goal.

Over the past 50 years, the global average temperature has risen by almost $1{ }^{\circ} \mathrm{C}$, from 13.87 in 1950 to 14.53 in 2004. Since the start of temperature registration, more than a hundred years ago, it has reached the highest average annual temperature in the world. marked over the past 20 years. For 300 years of the industrial revolution, the concentration of carbon dioxide in the atmosphere has increased by $31 \%$, including $18 \%$ since 1960 . The more the temperature rises, the less the ocean is able to absorb soot. It is established that its content in the ocean is 50 times higher than in the atmosphere. As the ocean temperature rises, their ability to absorb soot from the atmosphere decreases. it

Foreign trade activities cover a wide range of energy trade. A certain influence on the energy strategy of the two countries is exerted by the current viewpoint in the countries that oil companies, being private, work "for themselves", do not share with the budget and do not even develop their own business, being satisfied with short-term profit.

The most promising project today is the development of the Karachaganak field, which is operated by Karachaganak Integrated Company (hereinafter - KIO), including British Gas, Agip, Texaco, and Lukoil. The total reserves of the field are 1.2 billion tons of oil and 1.35 trillion. cubic meters of gas. Production at the Tengiz field (whose total reserves are estimated at 2.7 billion tons of oil) is constantly growing. The development of the field is conducted by Tengizchevroil JV, which includes the companies Chevron Texaco Overseas, ExxonMobile, Kazmunaygas and LUKARCO.

About $60 \%$ of foreign investment accounted for oil and gas companies.

Foreign trade activities cover a wide range of energy trade. A certain influence on the energy strategy of the two countries is exerted by the current viewpoint in the countries that oil companies, being private, work "for themselves", do not share with the budget and do not even develop their own business, being satisfied with immediate profit.

Opposite view is held by those who believe that with the strengthening of the public sector, superprofits of the oil business and supplementing the budget and the Stabilization Fund of the state appear.

According to scientists of the Institute for the Strategic Development of the Fuel and Energy Complex, supported by the Government of Kazakhstan, the public sector ensures the creation of an oil business system. In percentage terms, the share of the state increased from 10 to $40 \%$, which is lower than in the USA, Great Britain, China, Norway, France, Italy and other countries.

One of the main goals of the innovation method in scientific research is public-private partnerships and ensuring the reliability and sustainability of specialists and managers of science, increasing their creative potential and professional skills. The method of innovative teaching research is learning selflearning and self-development.

In the fuel and raw materials complex, the innovation policy will be focused on the development and implementation of modern methods of prospecting, exploration and monitoring of reserves, strategic and scarce types of mineral raw materials, increasing their recoverability and processing, as well as the development of highly reliable and environmentally friendly transportation systems, in oil and gas complex - to increase the efficiency of geological exploration, increase production rate and recoverability at fields with hard-to-recover reserves and residual reserves oil stocks in flooded areas, construction of wells in the shelf zone and frozen rocks, deepening of gas and condensate processing to produce motor fuel and target chemical products, as well as creating highly reliable, environmentally friendly and lowenergy-intensive transportation systems;

in the oil refining industry - to increase the production of motor and jet fuels through the development of deep oil refining processes, developing and creating catalysts of a new generation, high-octane and oxygen-containing additives, as well as improving environmental safety and reducing energy intensity;

The lack of awareness of energy management and the lack of sufficient skills to implement energy efficiency measures is due to the fact that the requirements for energy efficiency have been tightened in a short time. This revealed a significant shortage of qualified technical inspectors. 
The technical potential of energy saving in the republic is estimated at the level of $27.75 \%$ of the total consumption of primary energy resources - 17.36 million tons n.er At the same time, in the conditions of Kazakhstan, the realization of only a part of this potential will be economically justified - $19 \%$ of the total consumption of primary energy resources, or about 12 million tons. er The necessary amount of investments for the realization of the economic potential is $\$ 4$ billion.

If the number of discoveries, inventions, their importance, the depth of the research, estimates scientific and technical activity commercial indicators characterize the innovation activity: profit, economic efficiency, competitiveness. World experience shows that only $33 \%$ of ideas reach a specific technical solution, of which only $15 \%$ have a successful commercial development, and only $9 \%$ of ideas reach production. Universities are able to perform basic and applied research. The appearance of territorial associations in the form of large scientific and educational centers (based on a large university) and other research organizations $(\mathrm{NTO}, \mathrm{OKB})$ is remarkable.

\section{CONCLUSION}

Over the past few years, the issue of improving energy efficiency and energy conservation in the Republic of Kazakhstan has received close attention. To regulate energy, the state sets high standards for both ordinary people and enterprises: the people pay a large tax for energy, so no one dares to be wasteful of electricity, as well as using gas, water, and enterprises set high standards for protection the environment. The Constitution of the country has such an article that says about the human right to live in a normal natural environment.

The study of the development of economic potential on the basis of public-private partnership in the oil and gas producing regions of Kazakhstan makes it possible to state with complete confidence that the total volume of reserves of raw materials at relatively new fields, forecasts for those in the process of geological and exploratory research, as well as the existing prerequisites for increasing reserves are sufficient grounds for the republic to become attractive for investments in the oil and gas industry about and neighboring countries and, of course, the Russian Federation.

\section{REFERENCES}

[1] Sibikin Yu.D., Sibikin M.Yu. Unconventional renewable energy sources. RadioSoft. M., 2008.

[2] Budreyko E.N., Zaitsev V.A. Introduction to industrial ecology. M .: Profobr. 1991.

[3] The website of the Ministry of Energy of the Republic of Kazakhstan http://energo.gov.kz/.

[4] http://www.kazee.kz/useful-information/solnechnaya-energetika/.

[5] Information and analytical portal of Samruk-Kazyna National Wealth Fund JSC http://sk.kz/page/oil-and-gaz

[6] RIA Novosti 31/01/2012 ASTANA, IA News-Kazakhstan. http://www.newskaz.ru/economy/20120131/2621930.html

[7] Official US Energy Statistics Report. Man and the environment. http://www.priroda.su/item/1189

[8] Statistical compilation "Environmental Protection and Sustainable Development of the Republic of Kazakhstan", Almaty 2005, Agency of the Republic of Kazakhstan on Statistics.

[9] Alshanov R.A. Kazakhstan in the world mineral market: problems and their solutions. Almaty, 2004. p. 16, 17.

[10] Niyazbekova S.U., Eginbayeva A.E. Elements of interaction between the state and business. Bulletin of the University "TURAN" Scientific journal № 3 (71), 2016. from 44-49

[11] Bizhanov D.T., Nurgabylov M.N., Abdrakhmanova R.S., Doshan A.S. PROBLEMS OF ECONOMIC SECURITY OF THE FUEL AND ENERGY RESOURCES OF THE COUNTRY. Report of the National Academy of Sciences of Kazakhstan №5, 2018 y. P. 66-72. http://reports-science.kz/index.php/en/archive. https://doi.org/10.32014/2018.2518-1483

УДК 332.4:621.2.

К.М. Утепкалиева, Р.К. Сабирова, Г.У. Кенбаева

Атырауского государственного университета имени Х.Досмухамедова, г.Атырау, Казахстан

\section{РАЗВИТИЕ ГОСУДАРСТВЕННО-ЧАСТНОГО ПАРТНЕРСТВА В НЕФТЕГАЗОВОЙ ОТРАСЛИ}

Аннотация. В статье рассматриваются возможные направления развития государственно-частного партнерства в нефтегазовой отрасли. Успехи в рациональном, эффективном освоении и использовании 
топливно-энергетических ресурсов в значительной мере определяются инновационной активностью предприятий, постоянным технологическим обновлением производства и подтверждает опыт успешных нефтегазодобывающих компаний, освоивших за последние 25-30 лет несколько поколений новых технологий. На сегодняшний день получило широкое распространение использование государственночастного партнерства для целей модернизации экономики, новые приоритеты в использовании практики данного партнерства диктуют новые теоретико-методологические подходы к оценке эффективности государственно-частного партнерства - проектов, которые приведут, по мнению авторов к дополнительным бюджетным доходам за счет роста инвестиций, производства и занятости.

Ключевые слова: минеральное сырье, минеральные ресурсы, энергетические ресурсы, материальное благосостояние, новые технологии, производство электроэнергии, электростанции, эффективность, мощность производства.

УДК 332.4:621.2.

К.М. Утепкалиева, Р.К. Сабирова, Г.У. Кенбаева

Х. Досмұхамедов атындағы Атырау мемлекеттік университеті, Атырау, Қазақстан

\section{МҰНАЙ-ГАЗ СЕКТОРЫНДАҒЫ МЕМЛЕКЕТТІК-ЖЕКЕ СЕРІКТЕСТІКТІ ДАМЫТУ}

Аннотация. Мақалада мұнай-газ саласында мемлекеттік-жекеменшік әріптестікті дамытудың мүмкін бағыттары талқыланды. Жанармай-энергетикалық ресурстарды ұтымды, тиімді игерудегі және пайдаланудағы табыстар, негізінен, кәсіпорындардың инновациялық белсенділігі, өндірістің үнемі технологиялық жаңаруы және соңғы 25-30 жылда жаңа технологиялардың бірнеше ұрпағын игерген табысты мұнай-газ компанияларының тәжірибесін растайды. Бүгінгі таңда экономиканы жаңғырту үшін мемлекеттік-жеке меншік серіктестіктерді кеңінен тарату, осы серіктестіктің тәжірибесін қолданудың жаңа басымдықтары мемлекеттік-жеке меншік серіктестіктің тиімділігін бағалаудың жаңа теориялық және әдіснамалық тәсілдерін - авторлардың пікірінше, қосымша бюджет кірістеріне әкелетін жаңа теориялық және әдіснамалық тәсілдерді талап етеді. өсу есебінен инвестициялар, өндіріс және жұмыспен қамту.

Түйін сөздер: минералды шикізат, минералдық ресурстар, энергетикалық ресурстар, материалдық әлауқат, жаңа технологиялар, электр энергиясын өндіру, электр станциялары, тиімділігі, өндірістік қуаты.

Information about authors:

Utepkaliyeva Kasulu Musaevna, candidate of economic Sciences, acting associated Professor of Atyrau state University named H. Dosmukhamedov, ORCID https://orcid.org/0000-0002-5230-0318

Sabirov form Kuandykovna - candidate of Economics, associated Professor, head of chair "Economy", Atyrau state University named H. Dosmukhamedov, ORCID https://orcid.org/0000-0002-9947-6564

Kenbaeva Gulzada Utegenovna - the specialty 6M050600-Economy, Atyrau state University named H. Dosmukhamedov, https://orcid.org/0000-0001-8114-4580 


\section{МАЗМҰНЫ}

Беспаева Р.С., Бугубаева Р.О., Мануэль Ф. Грела2. Көрсеткіштердің теңдестірілген жүйесі негізінде Щучинск-Бурабай курорттық аймағын дамытудың кешенді стратегиясын қалыптастыру ................................................................................ 5

Аюпова 3.К., Құсайынов Д.Ө.Азаматтық процесстерді жетілдірудегі интеграцияның кейбір қырлары...................... 13

Құсайынова А. А., Вальдемар Козловски, Геращенко И. П.Қазақстан республикасындағы міндетті әлеуметтік сақтандырудың қаржылық-құқықтық тетіктерінің ерекшеліктері.

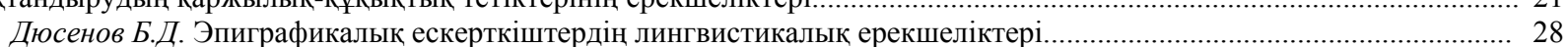

Джумадилова Ш.Г., Атабай Б.Ж. Қазақстандағы халықтың жинақтарының динамикасы......................................... 33

Карабалина А.А., Альситова А. Б., Кереймаганбетова Ж.Н., Абишева Н. М. Құндылық - рухани-адамгершілік

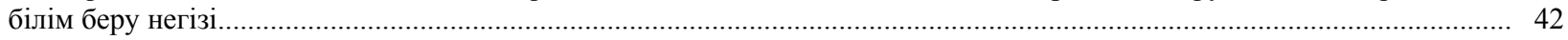

Кенжебаева Д.К., Өрмөрза Б. Ғ., Дашгин Махаммадли. Қазақстандық заманауи жастардың құндылығы............. 51

Нурманова А.Ш., Медерова Д.Е., Дюсенов Б.Д. «Бөкейхан әулетінің талдыбейіт қорымы» эпиграфикалық ескерткіштері тарихи дереккөз ретінде.

Кыдырова Ж.Ш., Онласынов Е.З., Абишова А.У., Шадиева А.А. Оңтүстік Қазақстан облысы сүт және сүт өнімдері нарығындағы жағдайды зерттеу ......

Абимова Г.У., Аманжолов Р., Мынбаева Б.Н., Ибрагимова Д.И. ЖОО-да биолог-студенттердің жобаларды

ұйымдастырылуы мен орындалуына даярлығы.......

Балтабаева А.Ю., Ризаходжаева Г. Мәдени интеграция үдерісіндегі жібек жолының феномені............................... 9

Бурганова Р.И., Абдугалина С.Е., Туякова А.Е. Студенттерге бағытталған білім беру арқылы білім сапасын

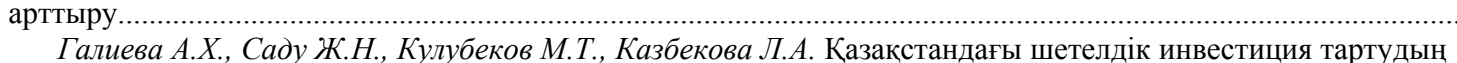

институционалдық жағдайын (талаптарын) бағалау..

Джалилов 3.Г., Батырхан Б.Ш. ХX ғ. екінші жартысындағы шетелдік исламтанушылардың ислам және саясат

туралы теориялық дискурсы.......

Джумабекова А.Т., Канатова А.Ж. Қаржылық ынтымақтастық жағдайларындағы Қазақстан республикасының

ұлттық банкінің өткізу механизмінің өзгеруі......

Дүйсен Г. М., Айтжанова Д. А. Қазақстан және Орталық Азия елдеріндегі көші-қон процесстері дамуының мәселелері мен ерекшеліктері

Есендұлова М.Н. Қазақстандағы « Қиын балаларды» оңалтудың және әлеуметтендірудің психологиялық ерекшеліктері

Жакишева К.М., Жуманова Д.Т., Мукашева Г.М. Экономиканың аграрлық секторының тұрақты дамуына арналған ауыл шаруашылық кәсіпорындарының қаржылық шарттарын мониторингінің рөлі.....

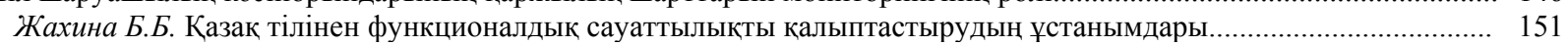

Идресова У.Х., Садуахасова 3.Ж., Муханова А.Т. Криминалистика....................................................................... 156

Савельева В. В. Қазақстандағы кредит технологиясын пайдалану және дамуының тарихи және педагогикалық базасы.

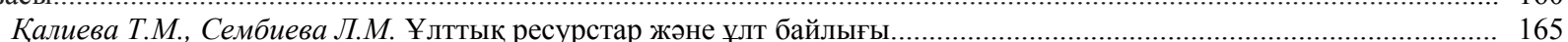

Каримова Р.У., Хаджиева Г.У. ҚХР Ұлттық саясаты контексіндегі ШҰАА-ның этносаяси және әлеуметтікэкономикалық трансформациясы мәселесі.

Керімбек Г., Молдашбаева Л., Джрауова Қ., Ажмухамедова А., Мизанова А. Қазақстан республикасының

республикалық бюджетіне түсетін салық түсімдерінің көрсеткіштерін талдау және бағалау.....

Жолдасбекова С.А., Парманкулова П.Ж., Асаналиев М.К. Мүмкіндігі шектеулі балаларды дамытудағы ұлттық ойындар

Молдакенова Е.К., Байгабулова К.К., Онаева Б.Т. БҚО-да инновациялық үрдістерді басқарудың аймақтық

аспектілігі жүйесінің дамудың жолдары.

Мұратова Г.К., Шаушенова А.Г., Жумасеитова С.Д., Онұварбаева М.Б.Білім беру үрдісінде бұлттық

технологияларын қолдану......

Несіпбеков E. Н., Аппакова Г.Н. Кәсіпорынның инвестициялық портфелін қалыптастырудың теориялық

Нургабылов М.Н., Барлыков Е.К., Егембердиева С.М. ҚР есеп өнеркәсібінің дамуының басқаруының трендсі....... 220

Нурымбетов Т.Я., Абишова А.У., Уразбаева Г.Ж., Кыдырова Ж.Ш., Байнеева П.Т., Абишо Н.У. Модернизациялық

жағдайындағы қр халқын әлеуметтік қолдауының басымдықтары.....

Рахимова С. А., Тургумбекова М. М. Қазақстан республикасындағы шағын және орта бизнестіңмемлекеттік қолдау

бағдарламалары және олардың тиімділігін жүзеге асыру шаралары.......................................................................... 233

Руденко Е.И. Орталық пен Оңтүстік Азия мемлекеттері арасындағы ұғынудың бұрмалануы - «Жұмсақ күш»

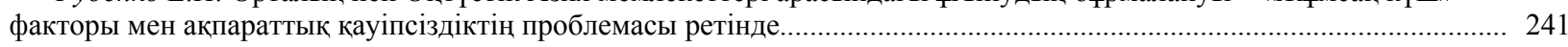

Тохтабаева Ш. Қазына-сандық.......................................................................................................... 251

Утепкалиева К.М., Сабирова Р.К., Кенбаева Г.У. Мұнай-газ секторындағы мемлекеттік-жеке серіктестікті дамыту

Мыңбаев Д. Е. Банкте басқару есебін ұйымдастыру тұжырымдамасы...

Султанова Г.С. Жаңа формацияның экономисі - бакалаврдың кәсіби құзыреттілігін қалыптастырудың

Шаяхметова А.А. Университет жағдайында инклюзивті білім беру үшін педагогтарды оқыту....... 


\section{СОДЕРЖАНИЕ}

Беспаева Р.С., Бугубаев Р.О., Мануэль Ф. Грела. Формирование комплексной стратегии развития ЩучинскоБоровской курортной зоны на основе сбалансированной системы показателей. Аюпова 3.К., Кусаинов Д.У., Уинстон Наган. Некоторые грани интеграции в совершенствовании гражданского процесса.

Кусаинова А.А., Козловски Вальдемар, Геращенко И.П. Обзор некоторых особенностей финансово-правового механизма обязательного социального страхования в республике Казахстан......

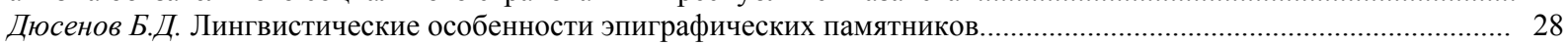

Джумадилова Ш.Г., Атабай Б.Ж.Динамика сбережений населения в Казахстане................................................... 33

Карабалина А.А., Альситова А. Б., Кереймаганбетова Ж.Н., Абишева Н. М. Ценность как базовая основа духовнонравственного образования.

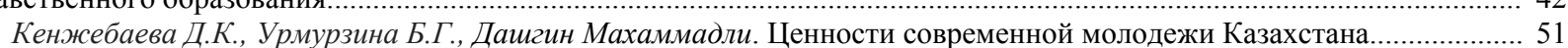

Нурманова А.Ш., Медерова Д.Е., Дюсенов Б.Д. Эпиграфические памятники «Некрополи талдыбейит династии

Бокейхановых» как исторический источник.

Кыдырова Ж.Ш., Онласынов Е.З., Абишова А.У., Шадиева А.А.Исследование ситуации на рынке молока и молочной продукции южно-казахстанской области

Абишова Г.У., Аманжолов Р., Мынбаева Б.Н., Ибрагимова Д.И. Готовность студентов-биологов к организации

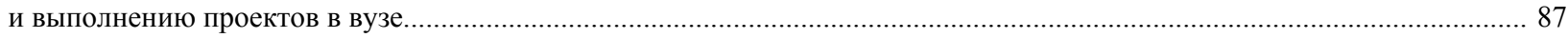

Балтабаева А.Ю., Ризаходжаева Г. Феномен великого шелкового пути в процессе культурной интеграции............... 91

Бурганова Р.И., Абдугалина С.Е., Туякова А.Е. Повышение качества образования посредством

студентоцентрированного обучения...

Галиева А.Х., Саду Ж.Н., Кулубеков М.Т., Казбекова Л.А. Оценка институциональных условий привлечения

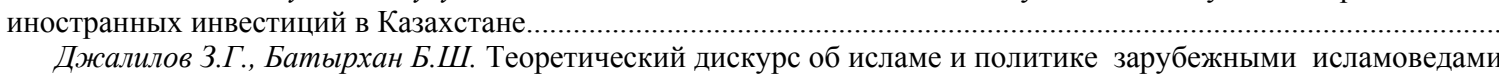
второй половины ХX в.

Джумабекова А.Т., Канатова А.Ж. Трансформация трансмиссионного механизма национального банка республики

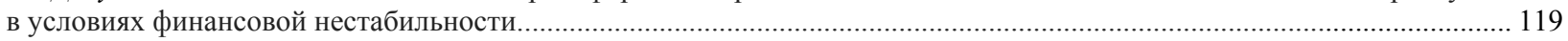

Дуйсен Г.М., Айтжанова Д.А. Проблемы и особенности развития миграционных процессов в Казахстане

и странах Центральной Азии.

Есенгулова М.Н. Психологические особенности реабилитации и социализации "Трудных подростков"

в Казахстане".

Жакишева К.М., Жуманова Д.Т., Мукашева Г.М.Роль мониторинга финансового состояния сельскохозяйственных

предприятий в обеспечении устойчивого развития аграрного сектора экономики.........................................................146

Жахина Б.Б. Принципы формирования функциональной грамотности казахского языка.......................................... 151

Идресова У.Х., Садуахасова 3.Ж., Муханова А.Т. Криминалистика......................................................................... 156

Савельева B.B. Исторические и педагогические основы формирования и разработки кредитной технологии

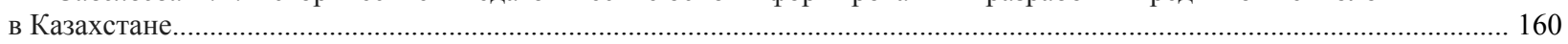

Калиева Т.М., Сембиева Л.М. Национальные ресурсы и богатство нации.................................................. 165

Каримова Р.У., Хаджиева Г.У. К вопросу об этно-политической и социально-экономической трансформации

СУАР в контексте национальной политики КНР

Керимбек Г., Молдашбаева Л., Джрауова Қ., Ажмухамедова А., Мизанова А. Анализ и оценка показателей

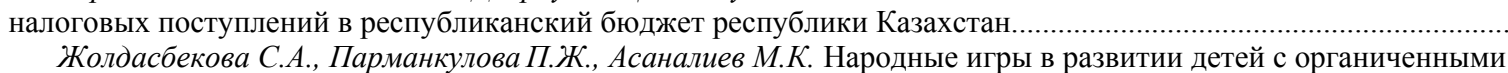

Жолдасбекова С.А., Парманкулова П.Ж., Асаналиев М.К. Народные игры в развитии детей с органиченными

Молдакенова Е.К., Байгабулова К.К., Онаева Б.Т.Пути развития системы регионального аспекта управления

инновационными процессами в АПК.

Муратова Г.К., Шаушенова А.Г., Жумасеитова С.Д., Онгарбаева М.Б. Применение облачных технологий

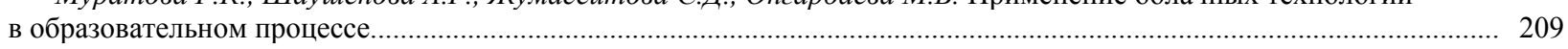

Несипбеков Е.Н., Аппакова Г.Н. Теоретические аспекты формирования инвестиционного портфеля предприятия. 214

Нургабылов М.Н., Барлыков Е.К., Егембердиева С.M. Тенденции управления развитием мясоперерабаты-

вающей отрасли в РК.

Нурымбетов Т.Я., Абишова А.У., Уразбаева Г.Ж., Кыдырова Ж.Ш., Байнеева П.Т., Абишов Н.У. Приоритеты

социальной поддержки населения РК в условиях модернизации................................................................................. 22

Рахимова С. А., Тургумбекова М. М. Программы государственной поддержки мсб в республике Казахстан и меры

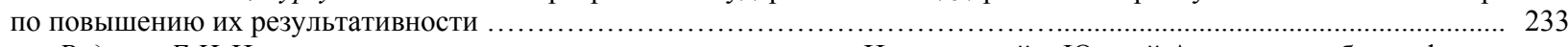

Руденко Е.И. Искаженность восприятия между государствами Центральной и Южной Азии как проблема фактора

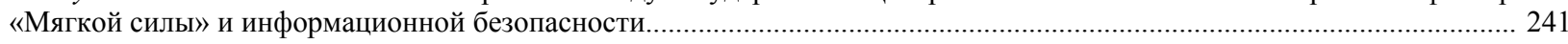

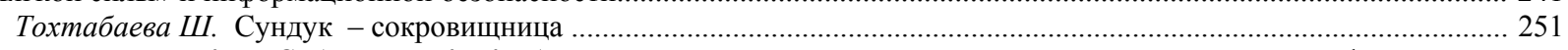

Утепкалиева К.М., Сабирова Р.К., Кенбаева Г.У.Развитие государственно-частного партнерства в нефтегазовой

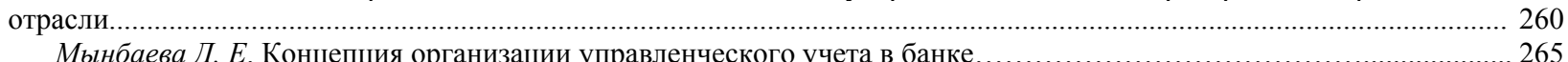

Мынбаева Д. Е. Концепция организации управленческого учета в банке...........................................2.
Султанова Г.С. Педагогические аспекты формирования профессиональных компетенций бакалавра - экономиста

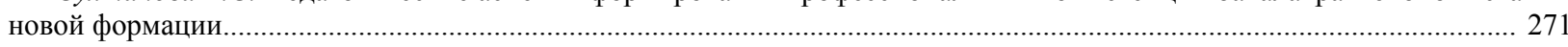

Шаяхметова А.А. О подготовке педагогических кадров к инклюзивному образованию в условиях вуза................ 277 


\section{CONTENTS}

Bespayeva R.S., Bugubayeva R.O., Manuel F. Grela. Formation of the complex strategy for development of the Schuchinsk-

Burabay resort area based on the balanced system of indicators.

Ayupova Z.K., Kussainov D.U., Winston Nagan. Some facets of integration in themodernization ofthe civil process..............13

Kussainova A.A., Kozlowski Waldemar, Gerashchenko I.P. The review of some features of the financial legal mechanism of obligatory social insurance in the republic of Kazakhstan...

Dyussenov B.D. Linguistic features of epigraphic monuments................................................................................ 28

Jumadilova Sh.G., Atabay B.Zh. Dynamics of the population savings in Kazakhstan.......................................................... 33

Karabalina A.A., Alsitova A.B., Kereimaganbetova Zh.N., Abisheva N.M. The values as critical factor of moral education... 42

Kenzhebayeva D.K., Urmurzina B.G., Dashqin Mahammadli. The modern youth values in Kazakhstan............................. 51

Nurmanova A.S., Mederova D.E., Dyussenov B.D. "Bokeykhanov dynasty taldybeyit necropolis" epigraphic monuments

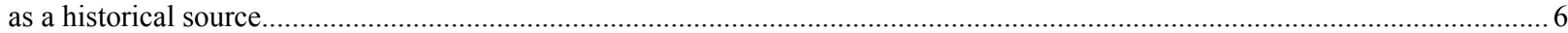

Kydyrova Zh.Sh., Onlasynov E.Z., Abishova A.U., Shadieva A.A.Research of the situation in the market of milk and dairy

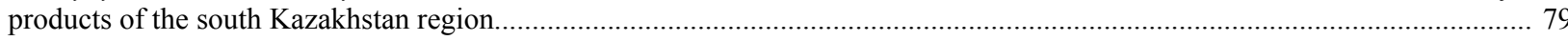

Abishova G.U., Amanzholov R.A., Mynbayeva B.N., Ibragimova D.I. Readiness of students-biologists for the organization

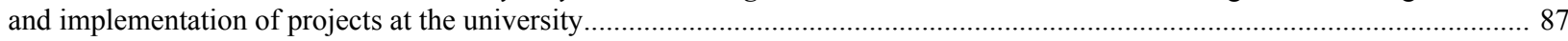

Baltabayeva A.Y., Rizakhojayeva $G$. The phenomenon of the great silk road in the cultural integration process................... 91

Burganova R.I., Abdugalina S.E., Tuyakova A.E. Improving the quality of education through student-centered education... 102

Galiyeva A.Kh., Sadu Zh.N., Kulubekov M.T., Kazbekova L.A. Assessment of the institutional terms of the foreign

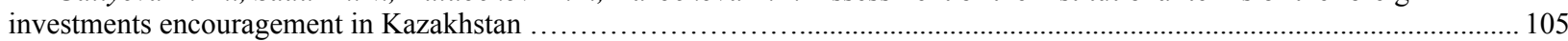

Dzhalilov Z.G. Theoretical discourse on islam and politics in foreign humanism of the second half of 20th century.......... 112

Dzhumabekova A.T., Kanatova A.ZH. Transformation of the transmission mechanism of the national bank of the republic

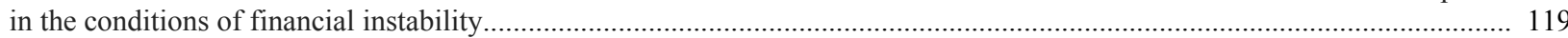

Suleimenov R.B. Problems and features of the development of migration processes in Kazakhstan and Central Asia.......... 124

Yesengulova M.N. Psychological aspects of reintegration and resocialization of "Trouble" adolescents in Kazakhstan....... 134

Zhakisheva K.M., Zhumanova D.T., Mukasheva G.M.The role of monitoring the financial condition of agricultural

enterprises in ensuring sustainable development of the agrarian sector of the economy......................................................... 146

Zhakhina B.B. Principles of functional literacy formation of the kazakh language....................................................... 151

Idresova U.Kh., Saduahasova Z.Zh., Mukhanova A.T. Criminalistics............................................................................. 156

Savelyeva $V . V$. Historicalandpedagogical bases of formation and development of credit technology in Kazakhstan........... 160

Kaliyeva T.M., Sembiyeva L.M. National Resources and national wealth.................................................................. 165

Karimova R., Hajiyeva G. Examining ethno-political and SOCIO-economic transformation of the xinjiang uyghur

autonomous region in the context of the PRC national policies........................................................................................ 176

Kerimbek G., Moldashbayeva L., Jrauova K., Azhmukhamedova A., Misanova A. Analysis and evaluation of reduction

of tax recovery of the republic of kazakhstan on the budget of the republic of Kazakhstan................................................. 185

Zholdasbekova S.A., Parmankulova P.Zh., Assanaliyev M.K. Folk games in the education of children with physical, mental and sensory disturbances..

Moldakenova E.K., Baygabulova K.K., Onaeva B.T. Ways of development of the system of the regional aspect of managing innovative processes in the APC.

Muratova G.K., Shaushenova A.G., Zhumassseitova C.D., Ongarbayeva M.B. Application of cloud technologies in the educational process......

Nurgabylov M.N., Barlikov E.K., Egemberdieva S.M. Trends of management of the development of meat processing industry in RK

Nurymbetov T.Ya., Abishova A.U., Urazbaeva G.Zh., Kydyrova Z.Sh., Baineeva P.T., Abishov N.U. Priorities of social support of the population of republic of Kazakhstan in the conditions of modernization........

Rakhimova S. A., Turgumbekova M. M. Programs of government support for sme in the republic of Kazakhstan and measures to enhance their efficiency.....

Rudenko Ye.I. Misperception between the states of Central and South Asia as a 'Soft power' and information security issue...

Tokhtabayeva Sh. Zh. Treasure-chest.

Utepkalieva K.M., Sabirova R.K., Kenbaeva G.U.Development of public private partnership approach in oil and gas

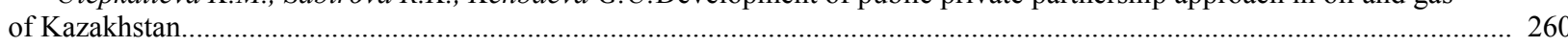

Mynbayeva D.E. Concept of organization of management accounting in bank ........................................................... 265

Sultanova G. S. Pedagogical aspects of formation of professional competence of the bachelor-economist of the new formation

Shayakhmetova A.A. On the training of teaching staff for inclusive education under the conditions of higher education institution. 


\section{PUBLICATION ETHICS AND PUBLICATION MALPRACTICE IN THE JOURNALS OF THE NATIONAL ACADEMY OF SCIENCES OF THE REPUBLIC OF KAZAKHSTAN}

For information on Ethics in publishing and Ethical guidelines for journal publication see http://www.elsevier.com/publishingethics and http://www.elsevier.com/journal-authors/ethics.

Submission of an article to the National Academy of Sciences of the Republic of Kazakhstan implies that the work described has not been published previously (except in the form of an abstract or as part of a published lecture or academic thesis or as an electronic preprint, see $\mathrm{http} / / / \mathrm{www} . e l s e v i e r . c o m / p o s t i n g p o l i c y)$, that it is not under consideration for publication elsewhere, that its publication is approved by all authors and tacitly or explicitly by the responsible authorities where the work was carried out, and that, if accepted, it will not be published elsewhere in the same form, in English or in any other language, including electronically without the written consent of the copyrightholder. In particular, translations into English of papers already published in another language are not accepted.

No other forms of scientific misconduct are allowed, such as plagiarism, falsification, fraudulent data, incorrect interpretation of other works, incorrect citations, etc. The National Academy of Sciences of the Republic of Kazakhstan follows the Code of Conduct of the Committee on Publication Ethics (COPE), and follows the COPE Flowcharts for Resolving Cases of Suspected Misconduct (http://publicationethics.org/files/u2/New_Code.pdf). To verify originality, your article may be checked by the originality detection service Cross Check http://www.elsevier.com/editors/plagdetect.

The authors are obliged to participate in peer review process and be ready to provide corrections, clarifications, retractions and apologies when needed. All authors of a paper should have significantly contributed to the research.

The reviewers should provide objective judgments and should point out relevant published works which are not yet cited. Reviewed articles should be treated confidentially. The reviewers will be chosen in such a way that there is no conflict of interests with respect to the research, the authors and/or the research funders.

The editors have complete responsibility and authority to reject or accept a paper, and they will only accept a paper when reasonably certain. They will preserve anonymity of reviewers and promote publication of corrections, clarifications, retractions and apologies when needed. The acceptance of a paper automatically implies the copyright transfer to the National Academy of sciences of the Republic of Kazakhstan.

The Editorial Board of the National Academy of sciences of the Republic of Kazakhstan will monitor and safeguard publishing ethics. 
Правила оформления статьи для публикации в журнале смотреть на сайте:

\section{www:nauka-nanrk.kz}

\section{social-human.kz}

Редакторы М.С. Ахметова, Т.А. Апендиев, Д.С. Аленов

Верстка на компьютере А.М. Кульгинбаевой

Подписано в печать 08.12.2018

Формат 60x881/8. Бумага офсетная. Печать - ризограф.

17,7 п.л. Тираж 500. Заказ 6.

Национальная академия наук $Р К$

050010, Алматы, ул. Шевченко, 28, т. 272-13-18, 272-13-19 